\title{
Purification and characterization of trypsin produced by gut bacteria from Anticarsia gemmatalis
}

\author{
Franciny Martins Pilon ${ }^{1}$ | Camila da Rocha Silva² | \\ Liliane Evangelista Visôtto $^{3} \quad$ Rafael de Almeida Barros ${ }^{1}$ \\ Neilier Rodrigues da Silva Júnior ${ }^{1}$ | Wellington Garcia Campos ${ }^{4}$ \\ Maria Goreti de Almeida Oliveira ${ }^{1}$ iD
}

\author{
${ }^{1}$ Departamento de Bioquímica e \\ Biologia Molecular, Instituto de \\ Biotecnologia Aplicada a Agropecuária- \\ BIOAGRO, Universidade Federal de Viçosa, \\ Viçosa, MG, Brazil \\ ${ }^{2}$ Instituto de Ciências Agrárias, Universidade \\ Federal de Viçosa Campus Rio Paranaíba, MG, \\ Brazil \\ ${ }^{3}$ Instituto de Ciências Biológicas e da \\ Saúde, Universidade Federal de Viçosa \\ Campus Rio Paranaíba, MG, Brazil \\ ${ }^{4}$ Departamento de Engenharia de Biossistemas, \\ Universidade Federal de São João Del Rei, São \\ João Del Rei, MG, Brazil

\section{Correspondence} \\ Maria Goreti de Almeida Oliveira, Laboratório \\ de Enzimologia, Bioquímica de Proteínas e \\ Peptídeos, Departamento de Bioquímica e \\ Biologia Molecular, Instituto de Biotecnologia \\ Aplicada a Agropecuária-BIOAGRO, \\ Universidade Federal de Viçosa, 219, Viçosa/ \\ MG 36570-000, Brazil \\ Email:malmeida@ufv.br \\ Funding Information \\ Grant sponsor: Coordenação de Aperfeiçoa- \\ mento de Pessoal de Nível Superior; Grant \\ sponsor: Fundação de Amparo à Pesquisa do \\ Estado de Minas Gerais; Grant sponsor: INCT \\ IPP; Grant sponsor: Conselho Nacional de \\ Desenvolvimento Científico e Tecnológico.
}

\begin{abstract}
Purification of active trypsin in the digestive process of insects is essential for the development of potent protease inhibitors (PIs) as an emerging pest control technology and research into insect adaptations to dietary PIs. An important aspect is the presence of proteolytic microorganisms, which contribute to host nutrition. Here, we purified trypsins produced by bacteria Bacillus cereus, Enterococcus mundtii, Enterococcus gallinarum, and Staphylococcus xylosus isolated from the midgut of Anticarsia gemmatalis. The trypsins had a molecular mass of approximately $25 \mathrm{kDa}$. The enzymes showed increased activity at $40^{\circ} \mathrm{C}$, and they were active at $\mathrm{pH}$ values 7.5-10. Aprotinin, bis-benzamidine, and soybean Kunitz inhibitor (SKTI) significantly inhibited trypsin activity. The L-1-tosylamido-2-phenylethylchloromethyl ketone (TPCK), pepstatin A, E-64, ethylenediamine tetraacetic acid, and calcium ions did not affect the enzyme activity at the concentrations tested. We infer the purified trypsins do not require calcium ions, by which they differ from the trypsins of other microorganisms and the soluble and insoluble trypsins characterized from A. gemmatalis. These data suggest the existence of different isoforms of trypsin in the velvetbean caterpillar midguts.
\end{abstract}

KEYWORDS

bacteria, pest control, protease inhibitor, trypsin 


\section{1 | INTRODUCTION}

There is a growing interest in alternative pest control methods for agricultural use, and endogenous mechanisms of plant resistance against herbivory are a major focus for possible application in integrated pest management (El-Latif, 2015; Huffaker, 2015; Jayachandran, Hussain, \& Asgari, 2013; Khandelwal et al., 2016; Lombardo, Coppola, \& Zelasco, 2016; Scott, Thaler, \& Scott, 2010). Protease inhibitors (PIs) are biopesticides widely recognized for their potential use in insect pest control, since the chronic ingestion of Pls affect the bioavailability of essential amino acids due to inhibition of digestive proteases (Lawrence \& Koundal, 2002).

Many studies have shown that PIs negatively affect the development, behavior, biochemistry, and physiology of the velvet caterpillar Anticarsia gemmatalis, a key pest of soybean (Macedo, Freire, Kubo, \& Parra, 2011; Moreira, Campos, Ribeiro, Guedes, \& Oliveira, 2011; Paixão et al., 2013; Pilon, Oliveira, \& Guedes, 2006). However, insects may adapt to Pls by an increase in protease production and synthesis of structurally different digestive enzymes or insensitive to PIs (Bown, Wilkinson, \& Gatehouse, 1997; Oliveira et al., 2013; Oppert, Morgan, Hartzer, \& Kramer, 2005; Souza et al., 2016; Tamaki \& Terra, 2015). Furthermore, proteases secreted by bacterial from the midgut of insects may improve herbivore adaptation to Pls and other mechanisms of plant resistance (Sethi et al., 2011; Shinde et al., 2017; Visôtto, Oliveira, Guedes, Ribon, \& Good-God, 2009a). In fact, there is strong evidence that trypsin activity in the midgut of A. gemmatalis is benefited by the insect gut microbiota (Visôtto et al., 2009a).

The successful use of Pls against insects depends on the target species and its ruling classes of proteases (Ahn \& ZhuSalzman, 2009; Moreira et al., 2011; Silva et al., 2015). Thus, the first steps toward understanding the adaptive mechanisms of A. gemmatalis to PIs must be supported by structural and functional studies of all isoforms of serine proteases, particularly trypsin, which is notoriously active in the insect gut. The trypsins (EC 3.4.21.4) cleave preferentially protein chains at the carboxyl side of basic amino acids, such as arginine and lysine (Mares-Guia \& Shaw, 1965). The enzymekinetic characteristics and tertiary structure of these trypsins provide the understanding of the connection and affinity between enzyme inhibitor (Cuccioloni et al., 2016; Joshi, Mishra, Suresh, Gupta, \& Giri, 2013; Liu, Zhang, Zeng, $\& \mathrm{Hu}, 2017)$.

The characterization of unpurified enzymes of A. gemmatalis, such as trypsin linked to the peritrophic membrane (Xavier, Oliveira, Guedes, Santos, \& Simone, 2005), soluble trypsin and cysteine proteases present in the insect gut (Mendonça, Oliveira, Visôtto, \& Guedes, 2012; Oliveira, Simone, Xavier, \& Guedes, 2005), and serine and cysteine proteases produced by gut bacterial (Pilon, Visôtto, Guedes, \& Oliveira, 2013) has been performed. Thus, as a step forward for the development of pest control strategies, through the use of PIs, and for the elucidation of possible mechanisms of adaptation of the velvetbean caterpillar to the inhibitors, the objective of this study was to purify and characterize trypsins produced by bacteria isolated from the gut of A. gemmatalis.

\section{2 | MATERIALS AND METHODS}

\section{1 | Microorganisms and culture condition}

The bacteria Bacillus cereus, Staphylococcus xylosus, Enterococcus mundtii, and Enterococcus gallinarum, used in this study, were isolated from the midgut of A. gemmatalis by Visôtto, Oliveira, Ribon, Mares-Guia, and Guedes (2009b).

Preinoculums were prepared in $25 \mathrm{ml}$ of brain heart infusion (BHI) culture medium with $0.1 \%$ bovine serum albumin (BSA) and maintained at $200 \mathrm{rpm}$ and $37^{\circ} \mathrm{C}$. An aliquot of $1 \mathrm{ml}$ of the preinoculum of each bacterial culture was removed at an absorbance at $600 \mathrm{~nm}$, equal to 0.2 , transferred to $50 \mathrm{ml}$ sterile BHI, with $0.1 \% \mathrm{BSA}$, and maintained at $200 \mathrm{rpm}$ and $37^{\circ} \mathrm{C}$ for $24 \mathrm{~h}$. At intervals of 2 at $2 \mathrm{~h}, 1 \mathrm{ml}$ aliquots were taken for determination of absorbance, and the amount of protein and enzymatic activity in cultures. 


\section{2 | Preparation of the enzyme extract}

One milliliter of each preinoculum was removed to an absorbance at $600 \mathrm{~nm}$ equal to 0.2 , and individually inoculated in $200 \mathrm{ml}$ of a BHI with $0.1 \% \mathrm{BSA}$, and maintained at $37^{\circ} \mathrm{C}, 200 \mathrm{rpm}$ for $4 \mathrm{~h}$ to $\mathrm{E}$. mundtii and S. xylosus, and $6 \mathrm{~h}$ for $\mathrm{B}$. cereus and E. gallinarum. The bacteria were centrifuged at $10,000 \mathrm{rpm}$ for $20 \mathrm{~min}$ at $4^{\circ} \mathrm{C}$. The supernatant containing the enzyme extract was removed and concentrated by ultrafiltration in an Amicon Ultra-15 with a porous membrane molecular limit of $3 \mathrm{kDa}$ (Millipore), and stored at $-20^{\circ} \mathrm{C}$ for later use as the enzyme source for purification.

\subsection{Protein concentration and trypsin activity}

The protein concentration of the extracts of bacterial cultures was determined as described by Bradford (1976), with BSA solutions of $0-0.2 \mathrm{mg} / \mathrm{ml}$ as standards.

Trypsin activity was determined as described by Erlanger, Kokowsky, and Cohen (1961), with a final concentration of a $0.5 \mathrm{mM} \mathrm{N}$ - $\alpha$-benzoyl-L-Arg- -nitroanilide (L-BApNA) in $0.1 \mathrm{M}$ Tris-HCl buffer (pH 8.2). Initial rates were determined by the formation of $\rho$-nitroanilide product by measuring absorbance at $410 \mathrm{~nm}$ versus time $(2.5 \mathrm{~min})$. The calculations were performed considering the specific molar extinction coefficient of $8,800 \mathrm{M}^{-1} \mathrm{~cm}^{-1}$ for the product.

\section{4 | Purification of bacterial trypsin}

Supernatants from enzyme extracts were subjected to precipitation with ammonium sulfate to $70 \%$ saturation. The amount of ammonium sulfate required to achieve this range of saturation was calculated based on the volume of supernatant of the culture that was subjected to precipitation (Scopes, 1994). The formed suspension was kept under agitation for $1 \mathrm{~h}$, and $1 \mathrm{~h}$ to stand under cooling. Subsequently, the extracts were centrifuged at 12,000 rpm for $60 \mathrm{~min}$ at $4^{\circ} \mathrm{C}$, and then the precipitates were collected. The precipitates were solubilized in Tris- $\mathrm{HCl}(10 \mathrm{mM}, \mathrm{pH} 7.5)$ and dialyzed overnight with the same buffer at $4^{\circ} \mathrm{C}$, using molecular membranes with pore limit of $3 \mathrm{kDa}$ (Sigma-Grade). After this period, centrifugation was performed $33,000 \mathrm{rpm}$ for $60 \mathrm{~min}$ at $4^{\circ} \mathrm{C}$ to remove impurities. The supernatants were removed after being subjected to affinity chromatography on a column of $\rho$-aminobenzamidine agarose ( $2.5 \mathrm{ml}$ ) $\left(\right.$ Sigma ${ }^{\circledR}$ ) equilibrated with Tris- $\mathrm{HCl}$ buffer $(0.05 \mathrm{M}, \mathrm{pH} 7.5)$ and $0.5 \mathrm{M} \mathrm{NaCl}$. Elution of the proteins was performed with glycine buffer $(0.05 \mathrm{M}, \mathrm{pH} 3.0)$ with continuous flow of $1 \mathrm{ml} / \mathrm{min}$ and collected in $1.5 \mathrm{ml}$ fractions. The eluted fractions were monitored by determining the $\mathrm{Abs}_{280}$, and determining trypsin activity. The fractions corresponding to the elution peak were pooled and stored at $-20^{\circ} \mathrm{C}$ for subsequent use in enzymatic characterization tests.

\section{5 | Polyacrylamide gel electrophoresis}

After each purification step, electrophoresis was performed with the samples following Laemmli (1970), with 12\% polyacrylamide gel in the presence of $0.1 \%$ sodium dodecyl sulfate (SDS-PAGE). The experiment was conducted at a constant voltage of $100 \mathrm{~V}$ for $1 \mathrm{~h}$ and $20 \mathrm{~min}$ at room temperature. The staining of the gels was performed with silver nitrate, according to Blum, Beier, and Gross (1987). After the electrophoretic run, the gels were fixed in $100 \mathrm{ml}$ of solution of methanol, glacial acetic acid, and water (50:12:38) for $2 \mathrm{~h}$, followed by three washes of $10 \mathrm{~min}$, with $50 \%$ ethanol solution. Subsequently, they were washed for $1 \mathrm{~min}$ in solution $0.02 \%$ sodium thiosulfate $\mathrm{w} / \mathrm{v}$, quickly washed with distilled water, and incubated for $15 \mathrm{~min}$ in a solution of $0.2 \%$ silver nitrate $\mathrm{w} / \mathrm{v}$ containing $37 \mu \mathrm{l}$ of $37 \%$ formaldehyde $\mathrm{v} / \mathrm{v}$. Gels were treated with the developing solution ( $4 \%$ sodium carbonate, $2 \mathrm{ml} 0.02 \%$ sodium thiosulfate solution, and 50 $\mu \mathrm{l}$ of $37 \%$ formaldehyde) to visualize the protein bands. The reaction was stopped by adding acetic acid.

\subsection{Effect of $\mathrm{pH}$ and temperature}

The $\mathrm{pH}$ profiles for trypsin activity from the bacterial isolates were determined with L-BApNA in the following buffer systems at $50 \mathrm{mM}$ with $20 \mathrm{mM} \mathrm{CaCl}_{2}$ : citric acid/disodium phosphate $(\mathrm{pH}$ 3.0-6.5), Tris- $\mathrm{HCl}(\mathrm{pH}$ 7.58.5), glycine/sodium hydroxide ( $\mathrm{pH}$ 9.5-10.5), and disodium phosphate/sodium hydroxide ( $\mathrm{pH}$ 11.0). The effects of 
temperature on the enzyme activity were determined using the same substrate (L-BApNA) at temperatures ranging from $10^{\circ} \mathrm{C}$ to $50^{\circ} \mathrm{C}$, using a spectrophotometer (Thermo Scientific UV-VIS, model Evolution 200) with temperature control system.

\subsection{Kinetic parameters}

The determination of the kinetic parameters, $K_{M}$ and $V_{\max }$, were performed in the buffers, and in the best activities temperatures obtained using L-BApNA in a concentration range varying from 0.05 to $2.0 \mathrm{mM}$. Kinetics parameters were estimated by nonlinear regression (Michaelis-Menten equation) with the curve-fitting procedure of Sigma Plot (Systat, 2008).

\subsection{Effect of $\mathrm{CaCl}_{2}$ and PIs}

The effects of calcium ions on the enzyme activity were measured by the addition of different concentrations of $\mathrm{CaCl}_{2}(5-30 \mathrm{mM})$ in the reaction mixture, using the temperature of $40^{\circ} \mathrm{C}$ and buffers with pH where best activity was obtained for each isolate (pH 7.0 to B. cereus, pH 9.5 to E. mundtii, pH 8.5 to E. gallinarum and S. xylosus).

Different PIs were selected and tested on enzyme activity in different concentration ranges according to their estimated $K_{\mathrm{i}}$. Inhibition assays were performed with the following inhibitors: aprotinin (1.0-2.0 $\mu \mathrm{M}$ ), bis-benzamidine (10$40 \mu \mathrm{M})$, soybean Kunitz trypsin inhibitor-SKTI (0.5-1.5 $\mu \mathrm{M}), \mathrm{N}$ - $\alpha$-tosyl-L-phenilalanine chloromethyl ketone-TPCK (5-20 $\mu \mathrm{M})$, pepstatin A (1.0-2.0 $\mu \mathrm{M}), \mathrm{E}-64(5.0-50 \mu \mathrm{M})$, and ethylenediamine tetraacetic acid-EDTA (55-75 $\mu \mathrm{M})$. The enzyme extracts were incubated for 25 min with each inhibitor prior to the addition of substrate to the reaction mixture, time required for the occurrence of possible enzyme-inhibitor interaction. After this incubation, the trypsin activity was subsequently determined as previously described.

The results were submitted to analysis of variance (ANOVA) and Tukey's test $(P<0.05)$ using the PROC GLM program; SAS Institute (2001).

\section{3 | RESULTS}

\section{1 | Bacterial growth and trypsin activity}

The profile of growth of B. cereus, E. mundtii, E. gallinarum, and S. xylosus, isolated from the midgut of A. gemmatalis, and the trypsin activity produced by these microorganisms were describe as a function of time (Figure 1). The bacteria growth and the enzyme activity began immediately after the microbial inoculation in culture medium. The exponential growth of the microorganisms occurred in $4 \mathrm{~h}$ of incubation for B. cereus and E. mundtii, and $6 \mathrm{~h}$ for E. gallinarum and $S$. xylosus. From these times, the growth speed was reduced and the cultures entered the stationary phase.

Enzyme production was increased in the exponential phase and early stationary growth stage. The greater activity of the trypsin was obtained after $4 \mathrm{~h}$ of incubation for E. mundtii and S. xylosus, and after $6 \mathrm{~h}$ for B. cereus and E. gallinarum (Figure 1). During the stationary phase, when the bacteria had reached peak enzyme, the trypsin activity was low, suggesting that the enzyme production is associated with growth and metabolism of the active microorganisms.

According to these results, the times of increased activity of trypsin were selected: $4 \mathrm{~h}$ for E. mundtii and S. xylosus, and $6 \mathrm{~h}$ for B. cereus and E. gallinarum, to obtain the enzyme extract necessary for the purification step.

\subsection{Purification of bacterial trypsin}

The chromatographic profile for each purified enzyme (Figure 2) showed two predominant peaks after extensive washing with equilibration buffer. The first peak corresponds to proteins that do not have affinity for $\rho$-aminobenzamidine 


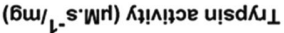

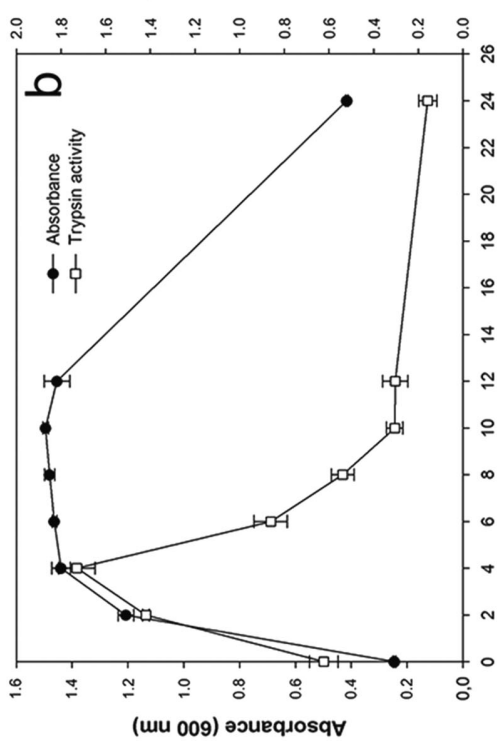

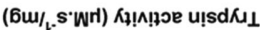

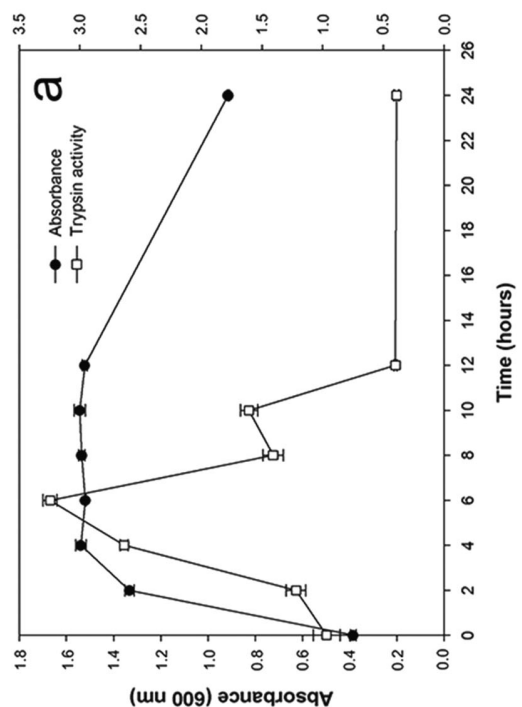

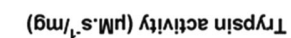

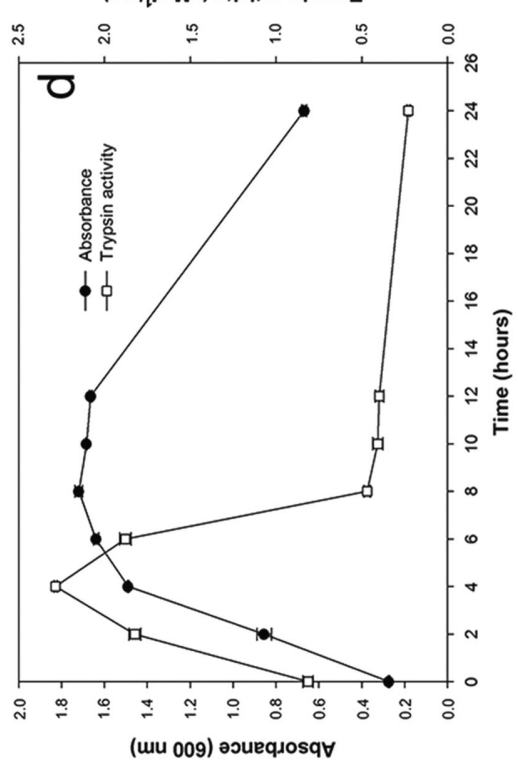

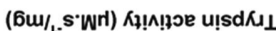

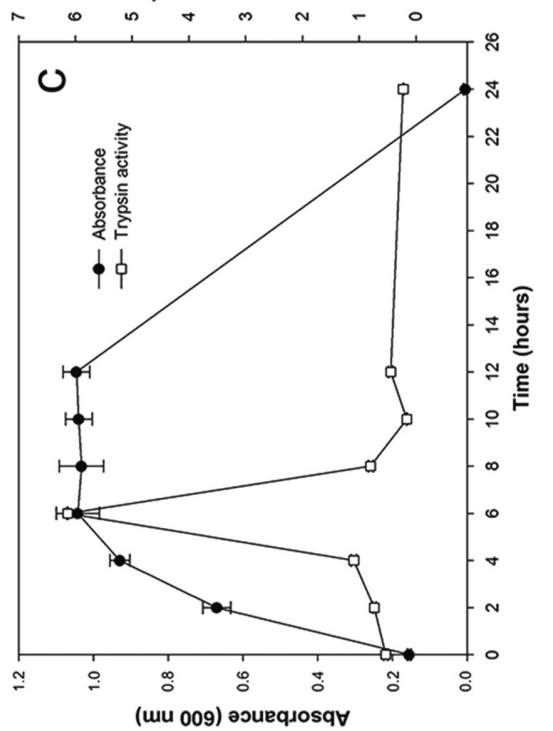

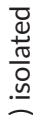

$\frac{0}{n}$

$\frac{\bar{x}}{x}$

క్

론

竞

문

जิ

$\frac{1}{\frac{2}{2}}$

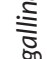

క్ర్ర

站

高

吾

ह

जิ

엉 음

ये

山े

茂

ज

ปँ

ज)

흔 $\frac{1}{\pi}$

๑

4

品

芩

을

훙

这

प है

ते जे

$\sum_{0}^{t} \frac{n}{0}$

山ै

는

光

등

त)

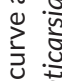

卉安

उั

닌

- $\frac{\overline{0}}{\varepsilon}$

แे

号

응 

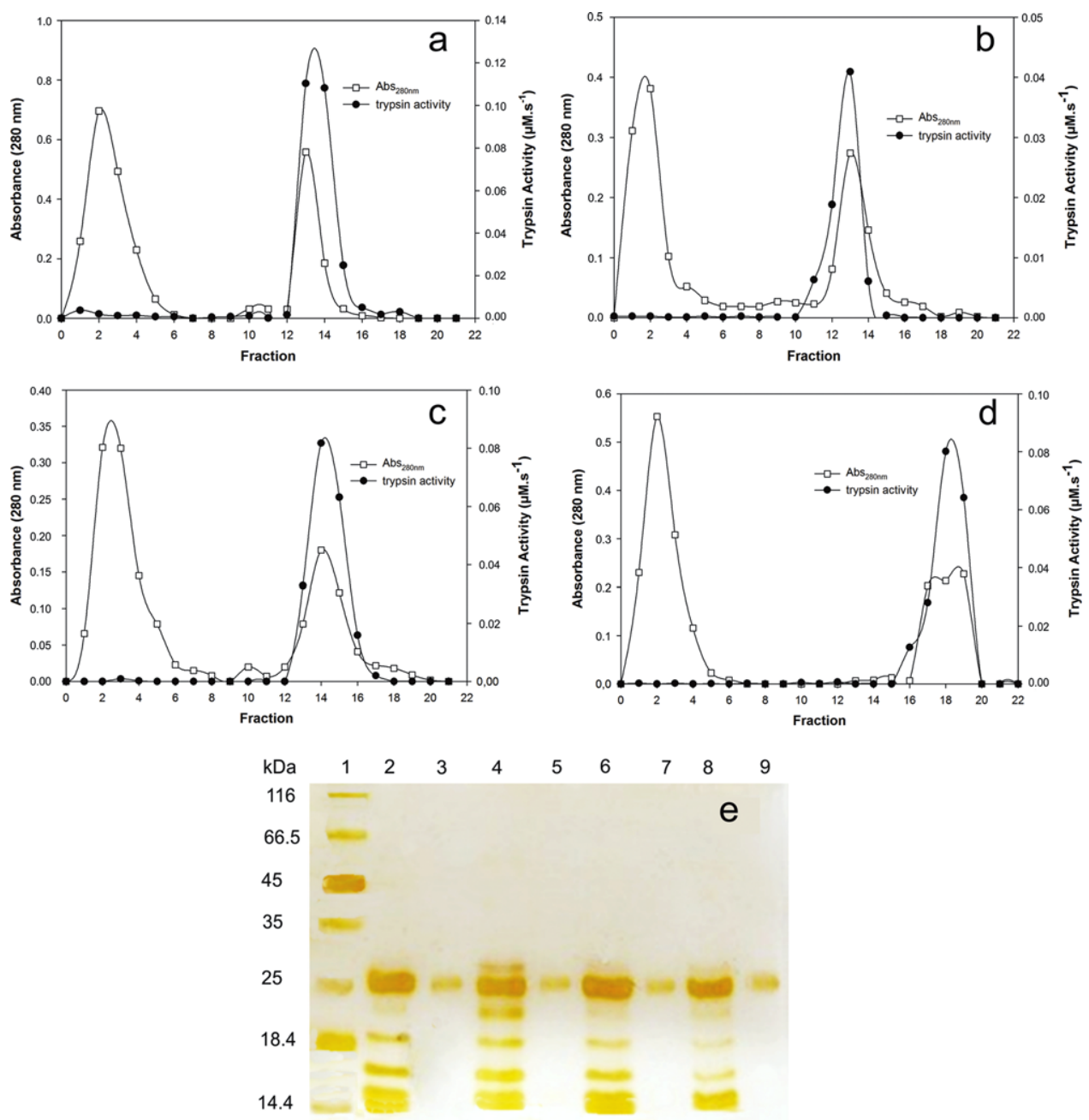

FIGURE 2 Elution profile of trypsin of Bacillus cereus (a), Enterococcus mundtii (b), Enterococcus gallinarum (c), and Staphylococcus xylosus (d) using the $\rho$-aminobenzamidine agarose column. Electrophoresis profile of the samples analyzed by SDS-PAGE (e); column 1: MW Standards; columns 2, 4, 6, and 8: crude enzyme extract of B. cereus, E. mundtii, E. gallinarum, and S. xylosus, respectively; columns 3, 5, 7, and 9: trypsin purified of B. cereus, E. mundtii, E. gallinarum, and S. xylosus, respectively

and do not possess the ability to efficiently hydrolyze the L-BApNA. The second minor protein peak corresponds to proteins that bind to $\rho$-aminobenzamidine, and has significant proteolytic ability against L-BApNA (Figure 2-d). These data are consistent with expectations, considering that trypsins are capable of hydrolyzing the L-BApNA substrate.

When subjected to electrophoresis, the samples eluted from the column migrate as a single band, while the crude extract showed several bands (Figure 2e), demonstrating the efficiency of the purification process. Comparing the distance of pattern migration (column 1) and the samples applied to columns 3, 5, 7, and 9, a molecular mass of approximately $25 \mathrm{kDa}$ was obtained.

The steps and yields of purification (Table 1) show that the trypsin from B. cereus and S. xylosus has higher purification factor (155.65-, 152.63-fold, respectively), due to higher recovery of enzyme activity to the end of the process, followed by 143.62 -fold of E. gallinarum and 140.36 -fold of E. mundtii. 
TAB LE 1 Steps in purification of trypsin produced by bacteria isolated from the midgut of Anticarsia gemmatalis

\begin{tabular}{|c|c|c|c|c|c|c|}
\hline Purification Steps & $\begin{array}{l}\text { Bacteria } \\
\text { Species }\end{array}$ & $\begin{array}{l}\text { Total } \\
\text { Protein (mg) }\end{array}$ & $\begin{array}{l}\text { Total } \\
\text { Activity } \\
\left(\mu \mathrm{M} \cdot \mathrm{s}^{-1}\right)\end{array}$ & $\begin{array}{l}\text { Specific } \\
\text { Activity } \\
\left(\mu \mathrm{M} \cdot \mathrm{s}^{-1} / \mathrm{mg}\right)\end{array}$ & $\begin{array}{l}\text { Purification } \\
\text { Factor (X) }\end{array}$ & Yield (\%) \\
\hline Crude extract & & 2.03 & 0.16 & 0.08 & 1.00 & 100.00 \\
\hline Ammonium sulfate & B. cereus & 0.16 & 0.14 & 0.87 & 10.87 & 87.50 \\
\hline$\rho$-Aminobenzamidine agarose & & 0.01 & 0.10 & 12.52 & 155.65 & 71.43 \\
\hline Crude extract & & 2.16 & 0.16 & 0.07 & 1.00 & 100.00 \\
\hline Ammonium sulfate & E. mundtii & 0.22 & 0.15 & 0.69 & 9.50 & 93.75 \\
\hline$\rho$-Aminobenzamidine agarose & & 0.01 & 0.10 & 10.20 & 140.36 & 66.67 \\
\hline Crude extract & & 2.30 & 0.17 & 0.07 & 1.00 & 100.00 \\
\hline Ammonium sulfate & E. gallinarum & 0.22 & 0.14 & 0.61 & 8.47 & 82.35 \\
\hline$\rho$-Aminobenzamidine agarose & & 0.01 & 0.09 & 10.37 & 143.62 & 64.29 \\
\hline Crude extract & & 1.99 & 0.16 & 0.08 & 1.00 & 100.00 \\
\hline Ammonium sulfate & S. xylosus & 0.21 & 0.14 & 0.69 & 8.57 & 87.50 \\
\hline$\rho$-Aminobenzamidine agarose & & 0.01 & 0.10 & 12.26 & 152.63 & 71.43 \\
\hline
\end{tabular}

\subsection{Effect of $\mathrm{pH}$ and temperature on trypsin activity}

The trypsins were highly active in the $\mathrm{pH}$ range of 7-9.5, and showed different values $(\mathrm{pH} 7.0$ for B. cereus, $\mathrm{pH} 9.5$ for E. mundtii, and $\mathrm{pH} 8.5$ for E. gallinarum and S. xylosus), but within the expected range of neutral to alkaline (Figure 3). As for the effect of temperature, all purified trypsin activity reached a plateau above $25^{\circ} \mathrm{C}$ (Figure 3).

\subsection{Kinetic characteristics}

The $K_{M}$ and $V_{\text {max }}$ values of bacterial enzymes and soluble and insoluble extract of velvetbean caterpillar are shown in Table 2. The $K_{M}$ values of trypsin of B. cereus, E. mundtii, E. gallinarum, and S. xylosus were $0.18,0.22,0.35$, and $0.21 \mathrm{mM}$, respectively. The $K_{M}$ obtained in this study are similar to those found for trypsins present in the soluble and insoluble extracts of the midgut of $A$. gemmatalis.

\subsection{Effect of $\mathrm{CaCl}_{2}$ and proteinase inhibitors}

The activity of the purified trypsin from B. cereus, E. mundtii, E. gallinarum, and S. xylosus was not affected by the presence of calcium ions in the concentrations tested. However, some inhibitors significantly reduced the enzymatic activity (Table 3). We found that aprotinin significantly reduced $(P<0.05)$ the activity of all enzymes due to increased concentration. The bis-benzamidine also affected significantly $(P<0.05)$ enzymatic activity in all concentrations; however, the concentration of $40 \mu \mathrm{M}$ was more effective. The SKTI inhibitor was also tested on bacterial enzymes, and it showed to be very effective in the concentration of $1.5 \mu \mathrm{M}$ for all enzymes. The TPCK, pepstatin A, E-64, and EDTA did not significantly affect $(P>0.05)$ the activity of the purified trypsins.

\section{I DISCUSSION}

Purification and characterization of insect trypsins have been performed in order to elucidate its structure and, thereby, to develop alternative insecticides molecules, such as PIs. Many active proteases in the intestine of insects are considered to be sensitive and others insensitive to PI, and little is known about the inhibitor and protease relationship of the associated microbiota. Recently, Shindle et al. (2017) reported that bacterial gut of Helicoverpa armigera 

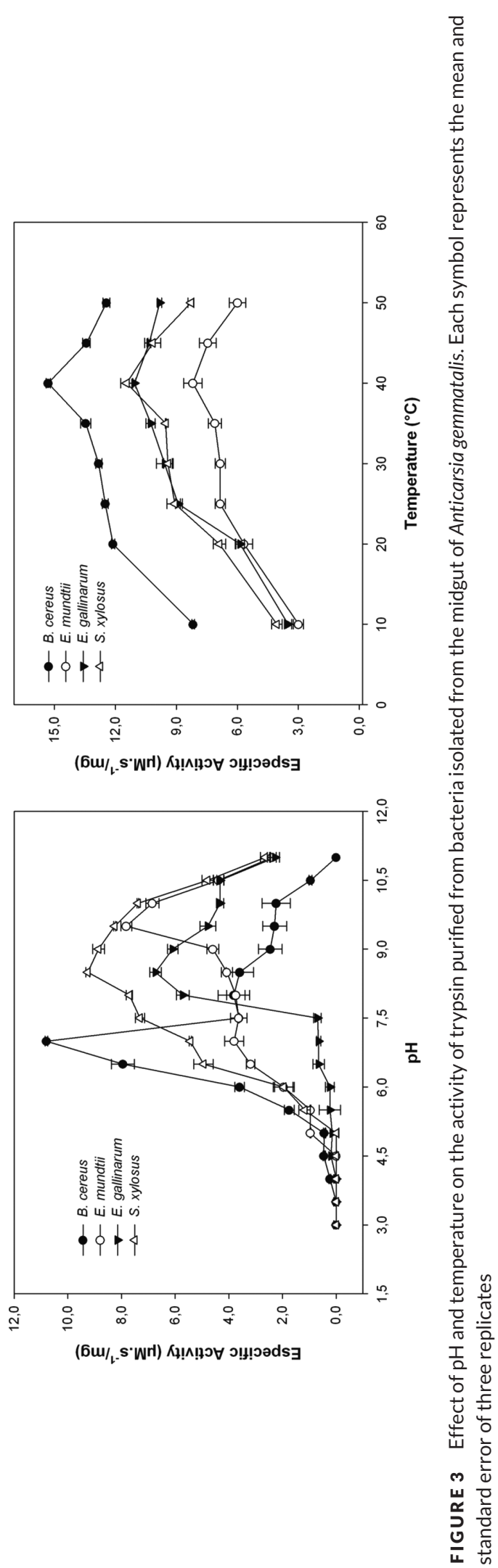
TAB LE 2 Kinetic parameters of trypsin purified from bacteria isolated from the midgut Anticarsia gemmatalis

\begin{tabular}{llll} 
& \multicolumn{3}{l}{ Kinetics Parameters } \\
\cline { 2 - 4 } Species & $K_{\mathrm{M}}(\mathrm{mM})$ & $\boldsymbol{V}_{\max }\left(\mathrm{nM} \cdot \mathrm{s}^{-1}\right)$ & Reference \\
\hline Bacillus cereus (purified extract) & 0.18 & 120.72 & Present work \\
\hline Enterococcus mundtii (purified extract) & 0.22 & 117.89 & Present work \\
\hline Enterococcus gallinarum (purified extract) & 0.35 & 116.79 & Present work \\
\hline Staphylococcus xylosus (purified extract) & 0.21 & 105.43 & Present work \\
\hline Anticarsia gemmatalis (soluble extract) & 0.32 & 480.00 & Oliveira et al. (2005) \\
\hline Anticarsia gemmatalis (insoluble extract) & 0.23 & 21.80 & Xavier et al. (2005) \\
\hline
\end{tabular}

TABLE 3 Effect of different inhibitors on the specific activity of trypsin purified from bacteria isolated from the midgut of Anticarsia gemmatalis

\begin{tabular}{|c|c|c|c|c|}
\hline \multirow{2}{*}{$\begin{array}{l}\text { Inhibitor/Concentration }(\mu \mathrm{M}) \\
\text { Aprotinin }\end{array}$} & \multicolumn{4}{|c|}{ Specific Activity of Trypsin $\left(\mu \mathrm{M} \cdot \mathrm{s}^{-1} \cdot \mathrm{mg}\right.$ Protein) } \\
\hline & B. cereus & E. mundtii & E. gallinarum & S. xylosus \\
\hline 0.0 & $12.41 \pm 0.23 a$ & $9.40 \pm 0.38 a$ & $9.56 \pm 0.19 a$ & $19.75 \pm 0.09 a$ \\
\hline 1.0 & $2.07 \pm 0.29 b$ & $0.02 \pm 0.01 b$ & $0.18 \pm 0.06 \mathrm{~b}$ & $0.17 \pm 0.08 b$ \\
\hline 1.5 & $0.16 \pm 0.10 b$ & $0.18 \pm 0.09 \mathrm{~b}$ & $0.18 \pm 0.02 b$ & $0.07 \pm 0.02 b$ \\
\hline 2.0 & $0.02 \pm 0.02 b$ & $0.22 \pm 0.11 b$ & $0.12 \pm 0.01 b$ & $0.03 \pm 0.03 b$ \\
\hline \multicolumn{5}{|l|}{ Bis-benzamidine } \\
\hline 0.0 & $12.41 \pm 0.23 a$ & $9.32 \pm 0.18 a$ & $10.75 \pm 0.14 a$ & $14.05 \pm 0.32 a$ \\
\hline 10.0 & $7.55 \pm 0.22 b$ & $2.21 \pm 0.24 b$ & $6.15 \pm 0.02 b$ & $6.75 \pm 0.27 b$ \\
\hline 20.0 & $5.22 \pm 0.36 c$ & $1.00 \pm 0.20 c$ & $3.96 \pm 0.19 c$ & $4.09 \pm 0.47 c$ \\
\hline 40.0 & $2.89 \pm 0.19 d$ & $0.31 \pm 0.05 d$ & $2.13 \pm 0.08 d$ & $1.28 \pm 0.05 d$ \\
\hline \multicolumn{5}{|l|}{ SKTI } \\
\hline 0.0 & $12.41 \pm 0.23 a$ & $7.02 \pm 0.33 a$ & $10.68 \pm 0.07 a$ & $14.00 \pm 0.05 a$ \\
\hline 0.5 & $7.30 \pm 0.33 b$ & $4.10 \pm 0.38 b$ & $0.46 \pm 0.04 b$ & $0.70 \pm 0.02 b$ \\
\hline 1.0 & $3.95 \pm 0.39 c$ & $0.03 \pm 0.01 c$ & $0.37 \pm 0.08 b$ & $0.13 \pm 0.01 c$ \\
\hline 1.5 & $1.51 \pm 0.14 d$ & $0.04 \pm 0.01 c$ & $0.14 \pm 0.008 c$ & $0.03 \pm 0.006 c$ \\
\hline \multicolumn{5}{|l|}{ TPCK } \\
\hline 0 & $13.07 \pm 0.35 a$ & $7.70 \pm 0.52 a$ & $9.63 \pm 0.14 a$ & $11.50 \pm 0.01 a$ \\
\hline $5-20$ & nd & nd & nd & nd \\
\hline \multicolumn{5}{|l|}{ Pepstatin A } \\
\hline 0 & $11.74 \pm 0.06 a$ & $9.32 \pm 0.18 a$ & $9.00 \pm 0.32 a$ & $13.86 \pm 0.33 a$ \\
\hline $1-2$ & nd & nd & nd & nd \\
\hline \multicolumn{5}{|l|}{$E-64$} \\
\hline 0 & $12.25 \pm 0.01 a$ & $9.04 \pm 0.06 a$ & $8.21 \pm 0.21 a$ & $9.51 \pm 0.25 a$ \\
\hline $5-50$ & nd & nd & nd & nd \\
\hline \multicolumn{5}{|l|}{ EDTA } \\
\hline 0 & $9.67 \pm 0.27 a$ & $7.80 \pm 0.59 a$ & $10.40 \pm 0.21 a$ & $14.44 \pm 0.02 a$ \\
\hline $55-75$ & nd & nd & nd & nd \\
\hline
\end{tabular}

Mean \pm SEM. Means followed by the same letter vertically do not differ statistically by Tukey's HSD test $(P>0.05)$. nd: nondetectable levels of inhibition. 
(Lepidoptera: Noctuidae) have an important impact on digestive physiology of this insect. Proteases synthesized by Bacillus sp. YP1 isolated from $\mathrm{H}$. armigera significantly degraded the PIs present in seeds. Such a finding suggests that bacterial proteases have significant contribution in the degradation and detoxification of host seed protein rich in Pls (Shindle et al., 2017). In this sense, it is crucial to know the set and kinetic-enzymatic aspects of all proteases involved in the digestion process. In the present study, we purified and characterized the trypsin produced by the gut bacteria of A. gemmatalis.

Research related to the role of the gut microbiota of insects suggests that, microorganisms synthesize a variety of digestive enzymes that contribute to host digestion, and that the catalytic potential of these proteins is closely related to the characteristics of the physiological environment in which they are secreted (Anand et al., 2010; Liang, Fu, \& Liu, 2015). We found that trypsin purified from bacteria showed bigger activity in neutral-alkaline medium. It is known that lepidopterous larvae have high luminal pH, which favors enzymatic activity at alkaline pH (Berenbaum, 1980; Terra \& Ferreira, 1994). Our results corroborate those reported for chymotrypsin-like produced by Bacillus subtilis isolated from the gut of H. armigera (Shinde, Shaikh, Padul, \& Kachole, 2012).

Proteases can be classified based on their sensitivity to various inhibitors (Elhoul et al., 2015; Rao, Aparna, Ghatge, \& Deshpande, 1998). Enzymes isolated from Streptomyces koyangensis (Elhoul et al., 2015) and Bacillus circulans (Benkiar et al., 2013) were characterized and classified as serine proteases through biochemical evaluations, including determination of the effect of Pls. Here, purified enzymes from gut bacteria of A. gemmatalis were significantly inhibited by a natural peptide that acts as a competitive inhibitor of trypsin, aprotinin (Laskowski \& Kato, 1980); by a synthetic molecule that acts as a parabolic partially competitive inhibitor of trypsin, called the bis-benzamidine (Junqueira, Silva, \& Mares-Guia, 1992) and by a soybean trypsin inhibitor, SKTI. These results, together with the molecular mass obtained, and to the absence of enzymatic inhibition upon the treatment with inhibitors TPCK (irreversible inhibitor of chymotrypsin), pepstatin A (inhibitor of aspartyl protease), E-64 (irreversible inhibitor of cysteine proteases), and EDTA (chelating $\mathrm{Ca}^{2+}$ and other divalent metal and acts on metalloproteases and proteases activated by metals), suggest that the enzymes evaluated in this study are trypsins. The weak impact of EDTA on the activity of these enzymes also suggests that such proteases do not rely on any divalent cation, consistent with the fact that proteases are generally independent of cofactors (Uttatree \& Charoenpanich, 2016).

The calcium ion regulates many biological systems by interacting with proteins with different affinities in different biological environments. The binding of $\mathrm{Ca}^{2+}$ to some proteins leads to an increase in stability and to changes in conformation of the calcium-binding proteins (Kotomán, Laczkó, Szabó, \& Simon, 2003). Numerous studies confirm the positive effect of calcium ions (3-10 mM) on serine protease activity isolated from B. circulans (Benkiar et al., 2013; Rao, Sathish, Ravichandra, \& Prakasham, 2009); S. koyangensis TN650 (Elhoul et al., 2015); Bacillus sp. strain B001 (Deng, Wu, Zhang, \& Wen, 2011); Bacillus laterosporus-AK1 (Arulmani et al., 2007); and Bacillus caseinilyticus (Mothe \& Sultanpuram, 2016). Many of these authors believe that the removal of $\mathrm{Ca}^{2+}$ from the strong binding site is associated with a significant decrease in stability, especially at high temperatures. Studies of DNA and sequence homology of bacterial proteases have demonstrated that the binding sites of calcium ions are variable in relation to the number and sequence of amino acids (Rao et al., 1998). Of the four calcium-binding sites in bacterial serine protease, two sites, that is, sites 3 and 4 , are absent in the thermolabile neutral proteases of Bacillus amyloliquefaciens and B. subtilis (NprA), whereas in NprB, Asn187 in site 3 is replaced by Arg. Such changes are responsible for the loss of thermostability and can be detected by sequence homology studies (Tran, $\mathrm{Wu}, \&$ Wong, 1991). In this study, the trypsin activities were not affected by calcium ions in the concentrations tested (5-30 mM). According to Rao et al. (1998), some proteases of bacterial origin do not require divalent ions to act efficiently.

Through the obtained results it can be inferred that bacteria present in the gut of A. gemmatalis synthesize trypsins. Previous studies have shown that these enzymes contribute significantly to protein digestion along with trypsins produced by the insect itself, demonstrating that there is a diversity of digestive trypsins active in A. gemmatalis. In addition, it provides basic information for analyses of molecular modeling and docking studies that will enable the development of potent organic Pls, peptides, or peptide mimetics, which could be used in plant protection and agricultural pest control. 


\section{ACKNOWLEDGMENTS}

The financial support provided by the National Council of Scientific and Technological Development (CNPq), CAPES Foundation (Brazilian Ministry of Education), Minas Gerais State Foundation for Research Aid (FAPEMIG), and National Institute of Science and Technology in Plant-Pest Interactions (INCTIPP) is greatly appreciated and acknowledged. The authors acknowledge Global Edico Services for revising and editing the manuscript.

\section{CONFLICT OF INTEREST}

The authors declare no conflict of interest.

\section{LITERATURE CITED}

Ahn, J. E., \& Zhu-Salzman, K. (2009). CmCatD, a cathepsin D-like protease has a potential role in insect defense against a phytocystatin. Journal of Insect Physiology, 55, 678-685.

Anand, A. A., Vennison, S. J., Sankar, S. G., Prabhu, D. I., Vasan, P. T., Raghuraman, T., ... Vendan, S. E. (2010). Isolation and characterization of bacteria from the gut of Bombyx mori that degrade cellulose, xylan, pectin and starch and their impact on digestion. Journal of Insect Science, 10, 1-20.

Arulmani, M., Aparanjini, K., Vasanthi, K., Arumugam, P., Arivuchelvi, M., \& Kalaichelvan, P. T. (2007). Purification and partial characterization of serine protease from thermostable alkalophilic Bacillus laterosporus-AK1. World Journal of Microbiology and Biotechnology, 23, 475-481.

Benkiar, A., Nadia, Z. J., Badis, A., Rebzani, F., Soraya, B. T., Rekik, H., ... Jaouadi, B. (2013). Biochemical and molecular characterization of a thermo- and detergent-stable alkaline serine keratinolytic protease from Bacillus circulans strain DZ100 for detergent formulations and feather-biodegradation process. International Biodeterioration \& Biodegradation, 83, 129138.

Berenbaum, M. (1980). Adaptive significance of midgut pH in larval Lepidoptera. American Naturalist, 115, 138-146.

Blum, H., Beier, H., \& Gross, H. (1987). Improved silver staining of plant proteins, RNA and DNA in polyacrylamide gels. Electrophoresis, 8, 93-99.

Bown, D. P., Wilkinson, H. S., \& Gatehouse, J. A. (1997). Differentially regulated inhibitor-sensitive and insensitive protease genes from the phytophagous insect pest, Helicoverpa armigera, are members of complex multigenes families. Insect Biochemistry and Molecular Biology, 27, 625-638.

Bradford, M. M. (1976). A rapid and sensitive method for the quantification of microgram quantities of proteins utilizing the principle of protein dye binding. Analytical Biochemistry, 72, 248-254.

Cuccioloni, M., Mozzicafreddo, M., Ali, I., Bonfili, L., Cecarini, V., Eleuteri, A. M., \& Angeletti, M. (2016). Interaction between wheat alpha-amylase/trypsin bi-functional inhibitor and mammalian digestive enzymes: Kinetic, equilibrium and structural characterization of binding. Food Chemistry, 213, 571-578.

Deng, A., Wu, J., Zhang, G., \& Wen, T. (2011). Molecular and structural characterization of a surfactant-stable high-alkaline protease AprB with a novel structural feature unique to subtilisin Family. Biochimie, 93, 783-791.

Elhoul, M. B., Jaouadia, N. Z., Rekika, H., Bejara, W., Touiouib, S. B., Hmidia, M., ... Jaouadi, B. (2015). A novel detergentstable solvent-tolerant serine thiol alkaline protease from Streptomyces koyangensis TN650. International Journal of Biological Macromolecules, 79, 871-882.

El-Latif, A. O. A. (2015). Biopotency of serine protease inhibitors from cowpea (Vigna unguiculata) seeds on digestive proteases and the development of Spodoptera littoralis (Boisduval). Archives of Insect Biochemistry and Physiology, 89, 117.

Erlanger, B. F., Kokowsky, N., \& Cohen, W. (1961). The preparation and properties of two new chromogenic substrates of trypsin. Archives of Biochemistry and Biophysics, 95, 271-278.

Huffaker, A. (2015). Plant elicitor peptides in induced defense against insects. Current Opinion in Insect Science, 9, 4450.

Jayachandran, B., Hussain, M., \& Asgari, S. (2013). An insect trypsin-like serine protease as a target of microRNA: Utilization of microRNA mimics and inhibitors by oral feeding. Insect Biochemistry and Molecular Biology, 43, 398-406.

Joshi, R. S., Mishra, M., Suresh, C. G., Gupta, V. S., \& Giri, A. P. (2013). Complementation of intramolecular interactions for structural-functional stability of plant serine proteinase inhibitors. Biochimica et Biophysica Acta, 1830, 50875094. 
Junqueira, R. G., Silva, E., \& Mares-Guia, M. (1992). Partial competitive parabolic inhibition of bovine trypsin by bisbenzamidines: A general model for the trypsin-like family of proteases. Brazilian Journal of Medical and Biological Research, 25, 873-887.

Khandelwal, N., Barbole, R. S., Banerjee, S. S., Chate, G. P., Biradar, A. V., Khandare, J. J., \& Giri, A. P. (2016). Budding trends in integrated pest management using advanced micro- and nano-materials: Challenges and perspectives. Journal of Environmental Management, 184, 157-169.

Kotomán, M., Laczkó, I., Szabó, A., \& Simon, L. M. (2003). Effects of Ca+2 catalytic activity and conformation of trypsin and $\alpha$-chymotrypsin in aqueous ethanol. Biochemical and Biophysical Research Communications, 304, 18-21.

Laemmli, U. K. (1970). Cleavage of structural protein during the assembly of the head of bacteriophage T4. Nature, 227, 680685.

Laskowski, J. M., \& Kato, I. (1980). Protein inhibitor of proteinases. Annual Review of Biochemistry, 49, 593-626.

Lawrence, P. K., \& Koundal, K. R. (2002). Plant protease inhibitors in control of phytophagous insects. Electronic Journal of Biotechnology, 5, 93-109.

Liang, X., Fu, Y., \& Liu, H. (2015). Isolation and characterization of enzyme-producing bacteria of the silkworm larval gut in bioregenerative life support system. Acta Astronautica, 116, 247-253.

Liu, Y., Zhang, G., Zeng, N., \& Hu, S. (2017). Interaction between 8-methoxypsoralen and trypsin: Monitoring by spectroscopic, chemometrics and molecular docking approaches. Spectrochimica Acta Part A: Molecular and Biomolecular Spectroscopy, 173, 188-195.

Lombardo, L., Coppola, G., \& Zelasco, S. (2016). New technologies for insect-resistant and herbicide-tolerant plants. Trends in Biotechnology, 34, 49-57.

Macedo, M. L. R., Freire, M. G. M., Kubo, C. E. G., \& Parra, J. R. P. (2011). Bioinsecticidal activity of Talisia esculenta reserve protein on growth and serine digestive enzymes during larval development of Anticarsia gemmatalis. Comparative Biochemistry and Physiology, Part C, 153, 24-33.

Mares-Guia, M., \& Shaw, E. (1965). Studies on the active center of trypsin. The binding of amidines and guanidines as models of the substrate side chain. Journal of Biological Chemistry, 240, 1579-1585.

Mendonça, E. G., Oliveira, M. G. A., Visôtto, L. E., \& Guedes, R. N. C. (2012). Midgut cysteine-proteinase activity in the velvetbean caterpillar (Anticarsia gemmatalis (Hübner)). Journal of Pest Science, 85, 117-123.

Moreira, L. F., Campos, W. G., Ribeiro, F. R., Guedes, R. N. C., \& Oliveira, M. G. A. (2011). Survival and developmental impairment induced by the trypsin inhibitor bis-benzamidine in the velvetbean caterpillar (Anticarsia gemmatalis). Crop Protection, 30 , 1285-1290.

Mothe, T., \& Sultanpuram, V. R. (2016). Production, purification and characterization of a thermotolerant alkaline serine protease from a novel species Bacillus caseinilyticus. Biotechnology, 6, 53-63.

Oliveira, C. F. R., Souza, T. P., Parra, J. R. P., Marangoni, S., Silva-Filho, M. C., \& Macedo, M. L. R. (2013). Insensitive trypsins are differentially transcribed during Spodoptera frugiperda adaptation against plant protease inhibitors. Comparative Biochemistry and Physiology, 165, 19-25.

Oliveira, M. G. A., Simone, S. G., Xavier, L. P., \& Guedes, R. N. C. (2005). Partial purification and characterization of digestive trypsin-like proteases from the velvetbean caterpillar, Anticarsia gemmatalis. Comparative Biochemistry and Physiology, 140, 369-380.

Oppert, B., Morgan, T. D., Hartzer, K., \& Kramer, K. J. (2005). Compensatory proteolytic responses to dietary proteinase inhibitors in the red flour beetle, Tribolium castaneum (Coleoptera: Tenebrionidae). Comparative Biochemistry and Physiology, 140, 53-58.

Paixão, G. P., Lourenção, A. L., Silva, C. R., Mendonça, E. G., Silva, P. L., Oliveira, J. A., ... Oliveira, M. G. A. (2013). Biochemical responses of Anticarsia gemmatalis (Lepidoptera: Noctuidae) in soybean cultivars sprayed with the protease inhibitor berenil. Journal of Agricultural and Food Chemistry, 61, 8034-8038.

Pilon, A. M., Oliveira, M. G. A., \& Guedes, R. C. N. (2006). Protein digestibility, protease activity and post-embryonic development of the velvetbean caterpillar (Anticarsia gemmatalis) exposed to the trypsin-inhibitor benzamidine. Pesticide Biochemistry and Physiology, 86, 23-29.

Pilon, F. M., Visôtto, L. E., Guedes, R. N. C., \& Oliveira, M. G. A. (2013). Proteolytic activity of gut bacteria isolated from the velvetbean caterpillar Anticarsia gemmatalis. Journal of Comparative Physiology, 183, 735-747.

Rao, C. S., Sathish, T., Ravichandra, P., \& Prakasham, R. S. (2009). Characterization of thermo- and detergent stable serine protease from isolated Bacillus circulans and evaluation of eco-friendly applications. Process Biochemistry, 44, 262-268.

Rao, M. B., Aparna, M. T., Ghatge, M. S., \& Deshpande, V. V. (1998). Molecular and biotechnological aspects of microbial proteases. Microbiology and Molecular Biology Review, 62, 597-635. 
SAS Institute Inc., SAS/STAT Software: Changes and Enhancements, Release 8.2, Cary, NC: SAS Institute Inc., 2001.

Scopes, R. K. (1994). Protein purification: Principles and practice (p. 375). New York: Springer-Verlag.

Scott, I. M., Thaler, J. S., \& Scott, J. G. (2010). Response of a generalist herbivore Trichoplusia ni to jasmonate-mediated induced defense in tomato. Journal of Chemical Ecology, 36, 490-499.

Sethi, A., Xue, Q. G., La Peyre, J. F., Delatte, J., \& Husseneder, C. (2011). Dual origin of gut proteases in Formosan subterranean termites (Coptotermes formosanus Shiraki) (Isoptera: Rhinotermitidae). Comparative Biochemistry and Physiology, 159, 261267.

Shinde, A. A., Shaikh, F. K., Gadge, P. P., Padul, M. V., Govindwar, S. P., \& Kachole, M. S. (2017). Conserved nature of Helicoverpa armigera gut bacterial flora on different host plants and in vitro interactions with PI proteins advocates role in host digestive physiology. Journal of the Saudi Society of Agricultural Sciences. https://doi.org/10.1016/j.jssas.2017.03.004

Shinde, A. A., Shaikh, F. K., Padul, M. V., \& Kachole, M. S. (2012). Bacillus subtillis RTSBA6 6.00, a new strain isolated from gut of Helicoverpa armigera (Lepidoptera: Noctuidae) produces chymotrypsin-like proteases. Saudi Journal of Biological Sciences, 19 , 317-323.

Systat Software, Inc. 2008: SigmaPlot for Windons, version 11.0. Systat Software, Inc. San Jose, California.

Silva, R. G. G., Vasconcelos, I. M., Filho, A. J. U. B., Carvalho, A. F. U., Souza, T. M., Gondima, D. M. F., ... Oliveira, J. T. A. (2015). Castor bean cake contains a trypsin inhibitor that displays antifungal activity against Colletotrichum gloeosporioides and inhibits the midgut proteases of the dengue mosquito larvae. Industrial Crops and Products, 70, 48-55.

Souza, T. P., Dias, R. O., Castelhano, E. C., Brandão, M. M., Moura, D. S., \& Silva-Filho, M. C. (2016). Comparative analysis of expression profiling of the trypsin and chymotrypsin genes from Lepidoptera species with different levels of sensitivity to soybean peptidase inhibitors. Comparative Biochemistry and Physiology, 196, 67-73.

Tamaki, F. K., \& Terra, W. R. (2015). Molecular insights into mechanisms of lepidopteran serine proteinase resistance to natural plant defenses. Biochemical and Biophysical Research Communications, 467, 885-891.

Terra, W. R., \& Ferreira, C. (1994). Insect digestive enzymes: Properties, compartmentalization and function. Comparative Biochemistry and Physiology, 109, 1-62.

Tran, L., Wu, X., \& Wong, S. (1991). Cloning and expression of a novel protease gene encoding an extracellular neutral protease from Bacillus subtilis. Journal of Bacteriology, 173, 6364-6372.

Uttatree, S., \& Charoenpanich, J. (2016). Isolation and characterization of a broad pH- and temperature-active, solvent and surfactant stable protease from a new strain of Bacillus subtilis. Biocatalysis and Agricultural Biotechnology, 8, 32-38.

Visôtto, L. E., Oliveira, M. G. A., Guedes, R. N. C., Ribon, A. O. B., \& Good-God, P. I. V. (2009a). Contribution of gut bacteria to digestion and development of the velvetbean caterpillar, Anticarsia gemmatalis. Journal of Insect Physiology, 55, $185-191$.

Visôtto, L. E., Oliveira, M. G. A., Ribon, A. O. B., Mares-Guia, T. R., \& Guedes, R. N. C. (2009b). Characterization and identification of proteolytic bacteria from the gut of the velvetbean caterpillar (Lepidoptera: Noctuidae). Environmental Entomology, 38, 1078-1085.

Xavier, L. P., Oliveira, M. G. A., Guedes, R. N. C., Santos, A. V., \& Simone, S. G. (2005). Trypsin-like activity of membrane-bound midgut proteases from Anticarsia gemmatalis (Lepidoptera: Noctuidae). European Journal of Biochemistry, 102, $147-153$.

How to cite this article: Pilon FM, Silva CdR Visôtto LE. Purification and characterization of trypsin produced by gut bacteria from Anticarsia gemmatalis. Arch Insect Biochem Physiol. 2017;96:e21407. https://doi.org/ 10.1002/arch.21407 